Trakya Eğitim Dergisi

Cilt 10, Sayı 2

May1s 2020, 429-443

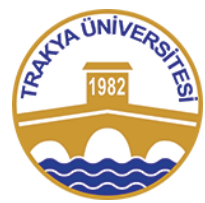

ISSN: $2630-6301$

Doi: $10.24315 /$ tred. 625860

Araştırma Makalesi/

Research Article
Trakya Journal of Education

Volume 10, Issue 2

May 2020, 429-443.

Gelis Tarihi: 27.09.2019.

\title{
Aktif Öğrenme Yaklaşımına Dayalı Hazırlanan Okul Öncesi Eğitim Programının Çocukların Sosyal Yetkinlik Düzeylerine Etkisi
}

\author{
The Effect of Active Learning Approach-Based Preschool Education Program on Children's \\ Social Competence Levels
}

\section{Hülya TORUN YETERGE ${ }^{1}$, Vesile YILDIZ DEMIRTAŞ ${ }^{2}$, Umut Haydar COŞKUN ${ }^{3}$, Gülser VARDARCI KAÇAR $^{4}$}

ÖZ: Öğrenen ve öğreten açısından yarattığı etki nedeniyle ilgi çekici olan aktif öğrenme, sosyal etkileşimi temel alan, ögrenenin ihtiyaçlarına odaklanan ve bu ihtiyaçlara cevap vermeyi amaçlayan, öğrenenlerin öğrenme süreçleri ile ilgili sorumluluk almalarına olanak tanıyan, bir yaklaşımdır. Çocukların gelecekteki yaşamları için belirleyici olan sosyal yetkinlik düzeylerinin geliştirilmesi amacıyla, erken çocukluk döneminde önleyici programlar ortaya koyup, uygulanmasını sağlamak büyük önem taşımaktadır. Buradan hareketle araştırmanın amacı, aktif öğrenme yaklaşımı ile hazırlanmış eğitim programının 5-6 yaş aralığındaki çocukların sosyal yetkinlik düzeyleri üzerindeki etkisini ortaya çıkarmaktır. Araştırmada ön-test ve son-test ile kontrol gruplu yar1-deneysel desen kullanılmıştır. 16 öğrenciden oluşan deney grubuna aktif öğrenme tekniklerini içeren 15 oturumluk eğitim programı uygulanıp, "sosyal yetkinlik ve davranış değerlendirme ölçeği” ve görüşme formları ile gerekli veriler toplanmıştır. Elde edilen veriler incelenmiş olup, son testlerde sosyal yetkinlik, kızgınlık saldırganlık ve anksiyete-içe dönüklük düzeylerinde deney grubu lehine anlamlı farklılık gözlenmiştir.

Anahtar sözcükler: Aktif öğrenme, sosyal yetkinlik, okul öncesi.

\section{Bu makaleye atıf vermek için /}

Torun Yeterge, H., Yıldız Demirtaş, V., Coşkun, U. H., Vardarcı Kaçar, G. (2020). Aktif öğrenme yaklaşımına dayalı hazırlanan okul öncesi eğitim programının çocukların sosyal yetkinlik düzeylerine etkisi. Trakya Eğitim Dergisi, 10(2), 429-443.

Cite this article as:

Torun Yeterge, H., Yıldız Demirtaş, V., Coşkun, U. H., Vardarc1 Kaçar, G. (2020). The effect of active learning approach-based preschool education program on children's social competence levels. Trakya Journal of Education, 10(2), 429-443.

\section{EXTENDED ABSTRACT}

\section{Introduction}

Active learning is an approach based social interaction, which focuses on the needs of the learner to respond them, enables the learner to take responsibility for the learning process, and effects the learners positively from the cognitive and affective aspects. For this approach to success depends on the learner's

\footnotetext{
${ }^{1}$ Doktora Öğrencisi, Gazi Üniversitesi, Eğitim Bilimleri Enstitüsü, Özel Eğitim Bölümü ORCID: 0000-0002-0042-4386

${ }^{2}$ Pof.Dr.,Dokuz Eylül Üniversitesi, Eğitim Bilimleri Enstitüsü, Özel Eğitim Bölümü ORCID: 0000-0002-4202-7733

${ }^{3}$ Doktora Öğrencisi, Dokuz Eylül Üniversitesi, Eğitim Bilimleri Enstitüsü, Özel Eğitim Bölümü ORCID:0000-0002-0892-8175

${ }^{4}$ Doktora Öğrencisi, Dokuz Eylül Üniversitesi, Eğitim Bilimleri Enstitüsü, Özel Eğitim Bölümü ORCID: 0000-0002-8372-427
} 
ability to make decisions and self-regulation about his learning process (Y1ldı-Demirtaş, 2016). It is, certainly, pleasing to develop self-regulation skills of the students with the active learning approach and to contribute to the future academic skills of early acquired skills. However, the skills that a child is expected to acquire in early childhood are not limited to academic skills. It is important for children to develop appropriate social skills such as communicate or interact with adults and peers, and to have the opportunity to express their feelings and thoughts. Meeting these social and emotional needs is an important predictor of social relationships, social behavior, social cohesion, and academic achievement. Therefore, it is of great importance to establish preventive programs in early childhood and to ensure the effective implementation of these programs to develop the social competence levels which are important determinants of children's future lives (Coplan, Ooi, Xiao and Rose - Krasnor, 2018; Çorapçı, Aksan, Arslan-Yalçın and Yağmurlu, 2010; Johnson and Johnson, 2008; Ogelman and Topaloğlu, 2014).Therefore, this study aims to determine the effect of the education program prepared with an active learning approach on the social competence levels of children between the ages of 5-6 calendar years.

\section{Method}

In this research-based on active learning approach, pre-test and post-test and quasi-experimental design with control and experimental groups were used. The independent variable of the research is the active learning education program prepared by the researchers aiming to improve the social competence levels of the children with the independent variable. In experimental designs, the aim is to explain the causeeffect relationship between the variables (Büyüköztürk, 2007). First of all, social competence and behavior evaluation scale and personal information form were applied to the children in the experimental (n: 16) and control (n: 16) groups. Then, the active learning education program developed by the researchers was applied to the children in the experimental group. No study was conducted with the children in the control group. Following the completion of the sessions, the social competence and behavior assessment scale was re-administered to the participants in the experimental and control groups. Also, semi-structured interviews were conducted with the children in the experimental group, their teacher and their parents. The data obtained were tabulated and analyzed.

\section{Findings}

When the findings obtained as a result of the implementation of the training program are examined, it is seen that the active learning-based training program increases the Social Competence levels of the children in the experimental group; especially Anger-Aggression and Anxiety-Introversion levels were found to decrease. In the interviews conducted with children for preschool teachers and their families for social validity, opinions about the effectiveness of the education program were expressed.

\section{Discussion and Conclusion}

It can be said that the educational program prepared with an active learning approach is related to increase the social competence level of the experimental group, and decrease the anxiety-introversion and anger-aggression levels, and the development in one area affecting other areas, especially in early childhood.

For instance, the development of peer relations in the classroom in the preschool period can effect social relations outside the classroom, this positive social change, decreases the level of anxiety and aggression, the positive picture that develops also improves self-regulation skills, and the development of self-regulation skills is important for future academic success. (Hemmeter, Snyder, Fox and Algina, 2016; LaFreniere, 2002; Mian, Wainwright, Briggs-Gowan and Carter, 2011). However, it should be kept in mind that, as the development in one step positively affects other areas, a negative situation in one area may affect another area negatively. For example, high levels of anxiety in early childhood lead to anxiety disorders in the future (Kagan and Snidman, 1999), while low social competence in early childhood has a criminal lifestyle in adulthood, substance use, drop out (Jones, Greenberg and Crowley, 2015), adaptation and behavior problems (Bornstein, Hahn and Haynes, 2010). For this reason, it is important to develop protective and preventive programs and to ensure the 
widespread implementation of the developed programs for the social and emotional development of pre-child children.

Another factor in the success of the education program is that active learning is an approach based on social interaction, focusing on the learner's feelings, thoughts, and needs, and encourages individuals to take responsibility and explain their ideas (Yıldız-Demirtaş, 2015). In addition to the social interaction of the education program, in the interviews with children, their parents, and their teachers, the children wanted to re-experience some of the techniques and activities in the education program at home or in the classroom. It can be assumed that the high level of family and teacher participation, positive perceptions and motivation of the students are the reasons for the results obtained. Preschool in Turkey in recent years, despite the increase in participation in education still compared to OECD countries (Kazu and Yilmaz, 2018) shows that progress has been inadequate. It also reveals the results that are needed in Turkey for increasing participation in early childhood education policy. Furthermore, considering that an active learning approach can be used effectively for different purposes in every age group, in-service training for teachers; This course aims to provide the prospective teachers with the necessary skills and technical knowledge in their undergraduate education. Also, incorporating environmental and familial factors into research on social competence can provide a more holistic assessment and allow for the development of more competent training programs.

\section{GİRIŞ}

1970’li yıllarda eğitim-öğretime bakışta köklü bir değişim meydana gelmiş, öğrenenin pasif dinleyen olduğu öğretmen merkezli davranışçı bakış açısının yerini, öğrenenin aktif katılımının, gelişim dönemlerinin ve bireysel özelliklerinin önemsendiği bilişsel yaklaşım almıştır. Öğrenenin merkeze alınması ve teknolojik gelişmelerin de etkisi ile yeni materyaller, yeni yöntemler ve yeni yaklaşımlar geliştirilmiş, ayrica geliştirilmeye de devam etmektedir (Çelik ve Buluç, 2016; Duman, 2013; Johnson ve Johnson, 2008).

Öğrenmeye ve öğretime ilişkin bu değişimin ardından araştırmacıların ve uygulayıcıların ilgisini çekerek büyük bir popülarite kazanan aktif öğrenme yaklaşımı, Avustralya ve Hollanda gibi ülkelerde köklü eğitim reformlarına neden olmuş, günümüzde nitelikli bir eğitim ortamının olmazsa olmaz koşulu haline gelmiştir (Prince, 2004; Açıkgöz, 2013). Bu durum aktif öğrenmenin beynin çalışma mekanizmasına uygun olması, aktif öğrenme ile bilginin daha kolay içselleştirilebilmesi, toplumun yaşam boyu öğrenen bireylere gereksinim duymas1, aktif öğrenmenin öğrenenlerin kendi aralarında da ilişki kurmasını kolaylaştırması gibi nedenlere dayanmaktadır (Chen, Huang, Gribbin ve Swan, 2018; Sibona ve Pourrezajourshari, 2018; Prince, 2002; Ott, Carpenter, Hamilton ve LaCourse, 2018; Açıkgöz, 2013).

Aktif öğrenme Açıkgöz (2013) tarafından öğrenenin öğrenme sürecinin sorumluluğunu taşıdığı, öğrenene öğrenme sürecinin çeşitli yönleri ile ilgili karar alma ve öz-düzenleme yapma firsatlarının verildiğgi karmaşık öğretimsel işlerle öğrenenin öğrenme sırasında zihinsel yeteneklerini kullanmaya zorlandığı bir öğrenme süreci olarak açıklanmaktadır. Kısaca öğrenenlerin öğrenme sürecine etkin katılımı, aktif öğrenme gruplarında yaşıtlarıyla etkileşimde bulunarak, zihinsel yeteneklerini kullanıp değişik öğretimsel işler üzerinde çalışarak ve öz-düzenlemeler yaparak gerçekleşmektedir (Yıldız, Demirtaş, 2015). Öğrenenlerin öz-düzenleme becerilerine sahip olması, planlama yapma, hedef koyma, öğrenme ortamını düzenleme, zamanı etkili kullanma, diğer öğrenenlerle birlikte öğrenme, geri bildirim alma ve verme gibi faktörleri kolaylaştırdığı için aktif öğrenmenin amacina ulaşmasında anahtar role sahiptir. Bu yanıyla aktif öğrenmenin öz-düzenleme becerilerini geliştirdiği; öz-düzenleme becerilerinin gelişiminin de aktif öğrenmenin amacina ulaşmasını kolaylaştırdığı söylenebilir. (Hofmann, Schmeichel ve Baddeley, 2012; Schunk, 2010; Cleary ve Zimmerman, 2004). Bunun dışında bu süreçte öğrenen kişinin hangi öğretimsel işler/sorular/problemler/etkinlikler üzerinde uğraştığı zihinsel yeteneklerini kullanmak açısından önemlidir. Kısaca aktif öğrenmede öğrenci, zihinsel yeteneklerini kullanması için zorlanır. Gerçekte öğrenme sürecinin kendisi, zihinsel yeteneklerin kullanılmasını gerektirir (Yıldız, Demirtaş, 2015).

Erken çocukluk döneminde çocukların çevresindeki yaşıtları ve yetişkinlerle etkileşim kurması, bu etkileşim sırasında sağlıklı bir şekilde duygu ve düşüncelerini ifade edebilme olanağı bulmaları 
sosyal ve duygusal gelişimleri açısından büyük bir önem taşımaktadır. Bu sosyal ve duygusal ihtiyaçların karşılanması da sosyal ilişkilerin, sosyal davranışların, toplumsal uyumunun ve akademik başarının önemli bir yordayıcısıdır (Avcıoğlu, 2003; Henson, 2003; Johnson ve Johnson, 2008; Möller, Nikolić, Majdandžić ve Bögels, 2016). Aktif öğrenme sürecinde de sosyal etkileşim önemli bir yer tutmaktadır. Aktif öğrenme uygulamaları öğrencilerin sosyalleşme ihtiyaçlarını birbirleriyle kurdukları sosyal etkileşim yoluyla gidererek öğrenme enerjilerini öğrenme etkinliklerine etkin bir şekilde katmaktadır (Yıldız, Demirtaş, 2015). Ayrıca erken çocukluk döneminde kimi çocuklarda dürtüsellik, öfke, karşıt gelme düzeylerinin yüksek olması, kimi çocuklarda ise içe kapanıklık ve sosyal ilişki geliştirme düzeylerinin düşük olması söz konusu olabilmekte, bu durum ergenlikte ve yetişkinlikte yıkıcı davranış problemlerine dönüşebilmektedir. (Campbell, 2002; Coplan, Ooi, Xiao ve Rose Krasnor, 2018; Ladd, 1999; Schindler, Kholoptseva, Oh, Yoshikawa, Duncan, Magnuson ve Shonkoff, 2015). Bu nedenlerle çocukların gelecekteki yaşamları için önemli bir belirleyici olan sosyal yetkinlik düzeylerinin geliştirilmesi amacıyla, erken çocukluk döneminde önleyici programlar ortaya koymak ve bu programların aktif bir şekilde uygulanmasını sağlamak büyük önem taşımaktadır. (Campbell, 2002;

Coplan, Ooi, Xiao ve Rose - Krasnor, 2018; Çorapçı, Aksan, Arslan-Yalçın ve Yağmurlu, 2010; Johnson ve Johnson, 2008; Ogelman ve Topaloğlu, 2014; Schindler ve diğ., 2015).

Buradan hareketle, bu araştırmanın amacı, aktif öğrenme yaklaşımı ile hazırlanmış eğitim programının 5-6 takvim yaşı aralığındaki çocukların sosyal yetkinlik düzeyleri üzerindeki etkisini ortaya çıkarmaktır. Araştırmada aşağıdaki sorulara cevap aranmıştır.

1. Aktif öğrenme yaklaşımı ile hazırlanmış eğitim programının öğrencilerin sosyal yetkinlik, Kızgınlık-Saldırganlık ve Anksiyete-İçe dönüklük düzeyleri üzerinde anlamlı bir fark göstermekte midir?

2. Aktif öğrenme yaklaşımı ile hazırlanmış eğitim programı çalışmalarına katılan ve gözleyen öğretmenin bu çalışmayla ilgili görüşleri nelerdir?

3. Aktif öğrenme yaklaşımı ile hazırlanmış eğitim programı çalışmalarına katılan çocukların bu çalışma ile ilgili görüşleri nelerdir?

4. Aktif öğrenme yaklaşımı ile hazırlanmış eğitim programı çalışmalarına katılan çocukların ebeveynlerinin bu çalışma ile ilgili görüşleri nelerdir?

\section{YÖNTEM}

Aktif öğrenme yaklaşımını temel alan bu araştırmada ön-test ve son-test ile kontrol gruplu yarıdeneysel desen kullanılmıştır. Araştırmanın bağımlı değişkeni çocukların sosyal yetkinlik düzeylerinin geliştirilmesi, bağımsız değişkeni çocukların sosyal yetkinlik düzeylerini geliştirmeyi amaçlayarak araştırmacılar tarafından hazırlanmış aktif öğrenme eğitim programıdır. Deneysel desenlerde amaç, değişkenlerin birbirleri arasındaki neden-sonuç ilişkisini açıklayabilmektir (Büyüköztürk, 2007).

Araştırmada ilk olarak deney ve kontrol grubunda yer alan çocuklara sosyal yetkinlik ve davranış değerlendirme ölçeği ile kişisel bilgi formu uygulanmıştır. Ardından deney grubunda yer alan çocuklara araştırmacılar tarafından geliştirilen aktif öğrenme yaklaşımına dayalı eğitim programı uygulanmıştır. Kontrol grubunda yer alan çocuklarla ise herhangi bir çalışma yapılmamıştır. Oturumların tamamlanmasının ardından deney ve kontrol grubundaki katılımcılara sosyal yetkinlik ve davranış değerlendirme ölçeği yeniden uygulanmıştır. Ayrıca deney grubunda yer alan çocuklarla, çocukların öğretmeniyle ve çocukların ebeveynleriyle yarı yapılandırılmış görüşmeler gerçekleştirilmiştir. 
Tablo 1.

Deney ve kontrol gruplarına ilişkin çalışma programı

\begin{tabular}{llll}
\hline & \multicolumn{1}{c}{ Deney Öncesi } & Deney & Deney Sonrası \\
\hline \multirow{2}{*}{ Deney } & $\begin{array}{l}\text { Sosyal Yetkinlik ve Davranış } \\
\text { Değerlendirme Ölçeği, } \\
\text { Kişisel Bilgi Formu }\end{array}$ & $\begin{array}{l}\text { Aktif Öğrenme } \\
\text { Programı }\end{array}$ & $\begin{array}{l}\text { Sosyal Yetkinlik } \\
\text { ve Davranış Değerlendirme } \\
\text { Ölçeği, Aile-Öğretmen ve } \\
\text { Öğrenci Görüş̧me Formları }\end{array}$ \\
\hline \multirow{2}{*}{ Kontrol } & & & \\
& $\begin{array}{l}\text { Sosyal Yetkinlik ve Davranış } \\
\text { Değerlendirme Ölçeği } \\
\text { Kişisel Bilgi Formu }\end{array}$ & $\begin{array}{l}\text { Herhangi bir program } \\
\text { uygulanmamıştır. }\end{array}$ & $\begin{array}{l}\text { Sosyal Yetkinlik ve } \\
\text { Davranış Değerlendirme } \\
\text { Ölçeği }\end{array}$ \\
\hline
\end{tabular}

\section{Örneklem}

Araştırma Manisa'da resmi bir Anaokulu'nda öğrenim gören, deney ve kontrol gruplarındaki 32 çocuk ile sürdürülmüştür. Araştırmanın örneklemi amaçlı örneklem ile seçilmiştir. Okul seçiminde, okul idaresinin, öğretmenlerin, ailelerin ve çocukların gönüllü olması, sınıf mevcudunun 20'nin altında olması, sınıfların fiziksel koşullarının aktif öğrenme oturumlarına olanak sağlayacak şekilde olması kriterleri dikkate alınmıştır. Çocukların yaş ortalaması deney grubu için $5.45(\mathrm{n}=16)$ ve kontrol grubu için $5.52(\mathrm{n}=16)$ 'dir ve her iki grupta da 8 kız, 8 erkek bulunmaktadır.

\section{Veri toplama araçları}

Çalışmada çocukların sosyal yetkinlik düzeylerini belirlemek için sosyal yetkinlik ve davranış değerlendirme ölçeği kullanılırken, çalışmanın sosyal geçerliğini belirlemek için ebeveyn, çocuk ve öğretmen yarı yapılandırılmış görüşme formları kullanılmıştır. Sosyal geçerlik deney grubuna uygulanan programın sosyal kabul edilirliğini belirlemek, arttırmak ve sürdürülebilir olup olmadığını belirlemek amacıyla değerlendirmeye alınır. (Schwartz ve Baer, 1991).

\section{Sosyal yetkinlik ve davranış değerlendirme ölçeği}

Özgün hali LaFreniere ve Dumas (1996) tarafından geliştirilen bu ölçek, toplamda 30 maddeden ve Sosyal Yetkinlik, Saldırganlık ve Anksiyete isimli 3 alt boyuttan oluşmaktadır. Öğretmen ya da ebeveyn tarafından da doldurulabilen bu form, likert tipi 6 basamaklı bir ölçektir. Ölçeğin Türkçe geçerlik ve güvenirlik çalışması Çorapçı, Aksan, Arslan-Yalçın ve Yağmurlu (2010) tarafından anaokuluna giden 417 çocuk (196 kız, 221 erkek) ile gerçekleştirilmiş, ölçeğin 30 maddeli ve 3 alt boyutlu yapısını koruduğu, madde korelasyon katsayılarının .41 'in üzerinde olduğu, son olarak alt boyutların cronbach alfa değerlerinin $.88, .87$ ve .84 olduğu bulgulanmıştır. Uygulamalardan 3 ay sonra yapılan test-tekrar test analizi sonucunda Sosyal Yetkinlik ve Saldırganlık boyutlarının puanlarının anlamlı bir şekilde yükseldiği, ancak Anksiyete puanlarında anlamlı bir değişimin olmadığı bulgulanmiştır.

\section{Çocuklar için yarı yapılandırılmış görüşme formu}

$\mathrm{Bu}$ form çocuklardan uygulanan programla ilgili olarak görüş almak amacıyla araştırmacılar tarafından geliştirilmiştir. Çocukların takvim yaşları ve gelişim dönemleri dikkate alınmış, formda yer alan soruların anlaşılır ve sade bir dille oluşturulmasına gayret edilmiştir. Oluşturulan bu form çocuk gelişimi ve özel eğitim alanında uzman 2 öğretim üyesine yönlendirilmiş, kendilerinden gelen eleştiriler doğrultusunda kapsam ile ilgili düzeltmeler yapılarak forma son hali verilmiştir. Son hali verilen form toplamda 6 maddeden oluşmaktadır.

\section{Öğretmen için yarı yapılandırılmış görüşme formu}

$\mathrm{Bu}$ form araştırmacılar tarafından geliştirilmiş, çocuk gelişimi ve özel eğitim alanında uzman 2 öğretim üyesinden görüş alınarak düzenlenmiştir. Formun son hali 4 sorudan oluşmaktadır. Bu form ile öğretmenin eğitim programı ile ilgili gözlem ve görüşlerine odaklanılması amaçlanmıştır. 


\section{Aileler için yarı yapılandırılmıș görüşme formu}

$\mathrm{Bu}$ formun amacı eğitim programının etkililiğinin ebeveynler tarafindan da gözlemlenip gözlemlenmediği durumundan yola çıkılarak, sosyal geçerlilik hakkında bilgi toplayabilmektir. Toplamda 5 maddeden oluşan bu form araştırmacılar tarafından geliştirilmiştir. Oluşturulan çocuk gelişimi ve psikolojik danışmanlık rehberlik alanında uzman 2 öğretim üyesinden görüş alınarak yeniden düzenlenmiştir.

\section{İşlem yolu}

Çalışma esnasında veri toplama araçlarının kullanımı ve işlemlerin gerçekleştirilmesi sırasında şu basamaklar izlenmiştir:

1. Veritabanlarında gerçekleștirilen alanyazın taraması.

2. Amaç ve kazanımların belirlenmesi.

3. Kullanılacak aktif öğrenme yöntem ve tekniklerin belirlenmesi.

4. Programı uygulayacak olan araştırmacıların aktif öğrenme yöntem ve teknikleri konusunda bu konuda uzman araştırmacı öğretim üyesi tarafından uygulamalı eğitime alınması

4. Veri toplama araçlarının hazırlanması. alınmas1.

5. Deney grubundaki öğrencilerin velilerine araştırma hakkında bilgi verilmesi ve izinlerin

6. Eğitim programında yer alacak etkinliklerin oluşturulması ve bu etkinliklerde hangi aktif öğrenme yöntem ve tekniğinin kullanılacağına karar verilmesi

7. Eğitim programında kullanılacak materyallerin hazırlanması.

8. Deney ve kontrol gruplarında ön testlerin uygulanması ve toplanması.

9. Toplanan verilerin çözümlenmesi ve grupların belirlenmesi.

10. Deney grubuna eğitim programı uygulanması.

11. Deney ve kontrol grubunda son testlerin yapılması.

12. Ölçümlerin çözümlenmesi.

\section{Denel işlemler}

Grupta güven ortamının oluşamaması ve grup dinamiğinin sürekliliği konusunda oluşabilecek olumsuz etkilerin engellenmesi ve denel işlemlerin sürdürülmesi ile ilgili planların uygulanmasında tutarlılık sağlanması için denel işlemler araştırmacılardan biri tarafindan yürütülmüştür.

Denel işlemler sırasıyla aşağıda verilmiştir.

1. Deney grubuna hazırlanan programda belirtilen oturum içeriklerine göre çalışmalar sürdürülmüş̧ür.

2. Çalışma ortamı grup üyelerinin rahatlıkla çalışacağı şekilde düzenlenmiştir.

3. Çalışmada kullanılacak materyaller ve plan önceden hazır bulundurulmuştur.

4. Oturumların içeriğinde farklı ve yaratıcı düşünmeye hizmet eden öğretimsel işlere/etkinliklere yer verilmiştir. (Örnek:Ayakkabıyı giymek dışında başka nerede, hangi amaçla kullanabiliriz? (Gez-birleş-ayrıl), Palyaçolara ayakkabılar hazırlama, (Düşün-eşleş-paylaş) Ayakkabınızın bir eşi kaybolsaydı ne olurdu? (Gez-birleş-ayrıl), Sinderallanın sihirli ayakkabısını çizme (Tereyağ-ekmek), vb.) Oturumların içeriği tablo 2'de belirtilen etkinlik başlıklarına göre düzenlenmiştir

5. Öğrencilerin etkinliklerde yaptıkları ürünler çalışma sırasında zaman zaman, kullanılan tekniğe uygun olarak, grup ortamında sergilenmiştir. Oturumların içeriği aşağıda belirtilen şekilde düzenlenmiştir. 
Tablo 2.

Aktif öğrenme yaklaşımına dayalı ĕ̆itim programı

\begin{tabular}{ll}
\hline Oturum İsmi & Oturumda Kullanılan Aktif Öğrenme Teknikleri \\
\hline & \\
1- Sihirli Ayakkabılarım & Gez-Birleş-Ayrıl, Düşün-Eşleş-Paylaş, Tereyağ-Ekmek \\
2- Bardak Çarkı & Hadi Anlat Bakalım, Hızlı Tur, Top Taşıma \\
& Gez-Birleş-Ayrıl, Tereyağ-Ekmek \\
3- Çaydanlık Kaynıyor & Gez-Birleş-Ayrıl, Düşün-Eşleş-Paylaş, Tereyağ-Ekmek \\
4- Koltuğum Kayboldu & Hizlı Tur, Top Taşıma, Gez-Birleş-Ayrıl \\
5- Çiçeklerimi Nereye Dikeceğim? & Hizlı Tur, Top Taşıma, Gez-Birleş-Ayrıl \\
6- Kalemin Tılsımı & Gez-Birleş-Ayrıl, Düşün-Eşleş-Paylaş, Hızlı Tur \\
7- Soğutucu Arıyorum & Gez-Birleş-Ayrıl, Düşün-Eşleş-Paylaş \\
8- Biri Makarna Mı Dedi? & Gez-Birleş-Ayrıl, Düşün-Eşleş-Paylaş, Tereyağ Ekmek \\
9- Pipetlerin Dansı & Hılı Tur, Düşün Eşleş Paylaş, Yuvarlak Masa \\
10- Evi Keşfet & Gez-Birleş-Ayrıl, Düşün-Eşleş-Paylaş \\
11- Kitap Ruhun Gıdasıdır & Gez-Birleş-Ayrıl, Düşün-Eşleş-Paylaş \\
12- Sandalyenin Farkı & Hızlı Tur, Top Taşıma, Gez-Birleş-Ayrıl \\
13- Van Gogh'un Ayçiçeği & Gez-Birleş-Ayrıl, Düşün-Eşleş-Paylaş, Yuvarlak Masa \\
14- Kütüphane Kedisi & Gez-Birleş-Ayrıl, Düşün-Eşleş-Paylaş \\
15- Öykülerin Gücü & Top Taşıma, Gez-Birleş-Ayrıl, Düşün-Eşleş-Paylaş \\
\hline
\end{tabular}

Tablo 2 de görüldüğü gibi aktif öğrenme yaklaşımına dayalı hazırlanan eğitim programı 15 oturumdan oluşmakta ve oturumlarda aktif öğrenme tekniklerinden "Gez- Birleş- Ayrıl, Düşün-EşleşPaylaş, Tereyağ-Ekmek, Hadi Anlat Bakalım, Hızlı Tur Top Taşıma ve Yuvarlak Masa” teknikleri yer almaktadir.

\section{Eğitim programının uygulanma süreci}

Oluşturulan aktif öğrenme programı özel eğitim alanında lisans üstü eğitim almış uzman özel eğitim öğretmeni bir lider tarafından yürütülmüsştür. Sınıf öğretmeni tüm uygulamalar sırasında sınfta yer alarak araştırmacıya destek olmuştur. Uygulayıcı aktif öğrenme alanında uzman olan öğretim üyesinden uygulamalı eğitim almıştır. Tüm uygulama boyunca programı uygulayan araştırmacı öğretim üyesi ile süpervizyon görüşmeleri gerçekleştirmiştir. Denel işlemlerden önce deneklerin aktif öğrenme tekniklerine alışmaları için 2 hafta toplam 4 oturum olacak şekilde 1sınma oturumları planlanıp, uygulanmıştır. Mart 2019 - Mayıs 2019 arasında haftada 2 oturum olmak üzere tüm uygulamalar gerçekleştirilmiştir. Oturumlar ortalama 90 dakika sürmüş, çocukların dikkat süreleri göz önüne alınarak 2 ara verilmiştir.

\section{Verilerin analizi}

Ön-test ve son-testlerde elde edilen veriler SPSS 22.0 paket programına aktarılmış, öncelikle basıklık ve çarpıklık değerlerine bakılmış, verilerin normal dağılmaması sebebiyle parametrik olmayan testlerin uygulanmasının uygun olacağı kararına varılmıştır. Bu sebeple deney ve kontrol gruplarındaki katılımcıların ön-test sonuçları arasında anlamlı bir fark bulunup bulunmadığı Mann-Whitney U Testi ile analiz edilmiştir. Daha sonra ön-test ve son-test sonuçları arasında fark bulunmadığı Wilcoxon İşaretli Sıralar Testi ile analiz edilmiştir. Ayrıca yarı yapılandırılmış görüşme formlarından elde edilen veriler tümevarım veri analizi tekniği ile analiz edilmiştir. Görüş birliği/(Görüş birliğii+Görüş ayrılığı) 
X 100 formülü güvenirliği sağlamak için uygulanmıştır. Sonuç olarak kodlayıcılar arası uyuşma oranı .85 bulunmuştur.

\section{BULGULAR}

\section{Sosyal yetkinlik ve davranış değerlendirme ölçeği ile ilgili bulgular}

$\mathrm{Bu}$ bölümde deney ile kontrol gruplarına ilişkin betimleyici istatistikler, eğitim programı öncesinde ve sonrasında uygulanan Sosyal Yetkinlik ve Davranış Değerlendirme Ölçeği'ne ilişkin bulgular yer almaktadır. İlk olarak Tablo 4'te betimleyici istatistiklere yer verilmiştir.

Tablo 3 .

Deney ve kontrol grubuna ilişkin tanımlayıcı istatistikler

\begin{tabular}{|c|c|c|c|c|c|c|c|}
\hline & Grup & & $\mathrm{n}$ & Ort. & ss & Minimum & Maximum \\
\hline & & Ön-test & 16 & 54.50 & 2.73 & 51 & 59 \\
\hline \multirow[t]{4}{*}{ Sosyal Yetkinlik } & Deney & Son-test & 16 & 58.00 & 2.35 & 55 & 60 \\
\hline & & Ön-test & 16 & 53.06 & 2.35 & 50 & 59 \\
\hline & Kontrol & Son-test & 16 & 53.31 & 2.12 & 51 & 58 \\
\hline & & Ön-test & 16 & 17.12 & 6.40 & 10 & 34 \\
\hline \multirow[t]{4}{*}{ Kızgınlık-Saldırganlık } & Deney & Son-test & 16 & 13.81 & 6.00 & 10 & 32 \\
\hline & & Ön-test & 16 & 17.25 & 4.49 & 11 & 25 \\
\hline & Kontrol & Son-test & 16 & 16.68 & 3.91 & 11 & 24 \\
\hline & & Ön-test & 16 & 17.31 & 6.60 & 10 & 22 \\
\hline \multirow[t]{3}{*}{ Anksiyete-İçe Dönüklük } & Deney & Son-test & 16 & 12.12 & 4.82 & 10 & 18 \\
\hline & & Ön-test & 16 & 16.75 & 2.68 & 11 & 27 \\
\hline & Kontrol & Son-test & 16 & 15.88 & 5.36 & 10 & 26 \\
\hline
\end{tabular}

Sosyal Yetkinlik ve Davranış Değerlendirme Ölçeği ile bir çocuğun gelişiminin risk altında olduğunun değerlendirilebilmesi için iki kriter söz konusudur. Çocuğun sosyal yetkinlik alt ölçeğinde $\% 10$ 'luk dilimin altında olması, aynı zamanda kızgınlık-saldırganlık ya da anksiyete-içe dönüklük alt boyutlarında ise \%10'luk dilimin üstünde olması beklenmektedir. Minimum değer sosyal yetkinlik için erkek çocuklar için 29 puan ve altı; anksiyete-içe dönüklük için 29 puan ve üstü; kızgınlık ve saldırganlık için 35 puan ve üstü belirlenmiştir (Çorapçı, Aksan, Arslan-Yalçın ve Yağmurlu, 2010). Ölçme aracından deney ve kontrol gruplarında yer alan çocukların ön-test ve son-testlerdeki minimum ve maksimum puanları incelendiğinde, gelişimi risk altında olan bir çocuğun araştırmanın örnekleminde yer almadığ 1 görülmüştür.

Tablo 4.

Katılımcıların eğitim programı öncesinde ölçme aracından aldıkları puanlara ait mann-whitney u testi sonuçları

\begin{tabular}{lcccccc}
\hline & Grup & $\mathrm{n}$ & Sira Ortalaması & Sira Toplamı & $\mathrm{U}$ & $\mathrm{p}$ \\
\hline Sosyal Yetkinlik & Deney & 16 & 18.91 & 302.50 & & \\
& Kontrol & 16 & 14.09 & 225.50 & 89.50 & \multirow{2}{*}{.141} \\
\hline Kızgınlık-Saldırganlık & Deney & 16 & 15.88 & 254.00 & & \\
& Kontrol & 16 & 17.13 & 277.00 & 118.00 & .704 \\
\hline Anksiyete-İçe Dönüklük & Deney & 16 & 15.69 & 251.00 & & \\
& Kontrol & 16 & 17.31 & 277.00 & 115.00 & .642 \\
\hline
\end{tabular}


Tablo 5.’e bakıldığında, deney ve kontrol grubunda yer alan çocukların uygulamalar öncesi gerçekleştirilen ön-testlerde aldıkları Kızgınlık-Saldırganlık, Sosyal Yetkinlik ve Anksiyete-İçe dönüklük puanları arasında istatistiksel olarak anlamlı bir fark bulunmamaktadır.

Tablo 5.

Katılımcıların eğitim programı sonrasında ölçme aracından aldıkları puanlara ait wilcoxon işaretli sıralar testi sonuçları

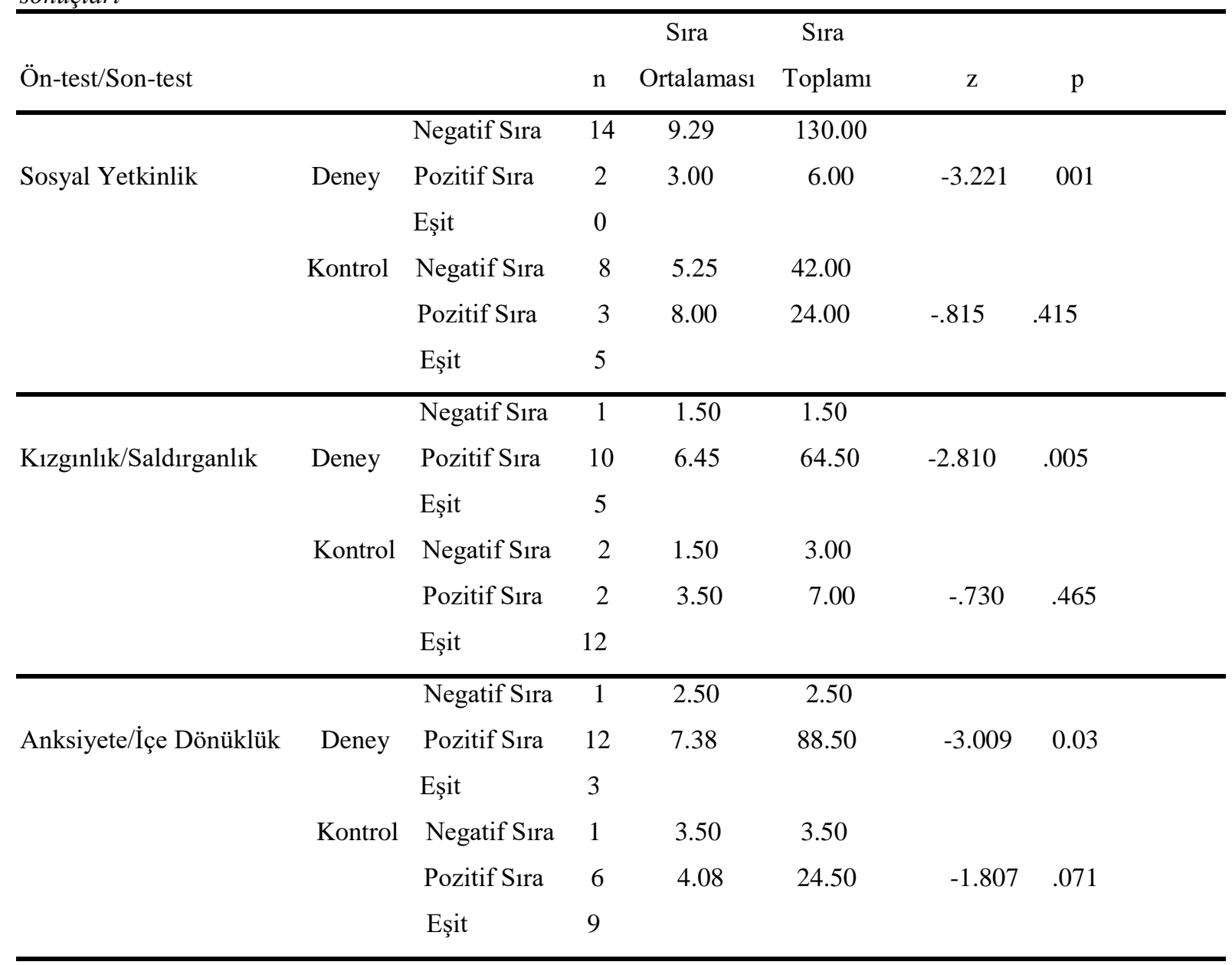

Tabloda da görüldüğ̈̈ Sosyal Yetkinlik ( $\mathrm{z}=-3.221, p<.05)$, Kızgınlık/Saldırganlık ( $\mathrm{z}=-2.810$, $p<.05)$, Anksiyete/İçe Dönüklük $(\mathrm{z}=-3.009, p<.05)$ alt boyutlarında deney grubundaki çocukların öntest ve son-test puanları arasında son-test lehine anlamlı bir fark vardır. Ayrica kontrol grubundaki çocukların Sosyal Yetkinlik ( $\mathrm{z}=.815, p>.05)$, Kızgınlık/Saldırganlık $(\mathrm{z}=.730, p>.05)$, Anksiyete/İçe Dönüklük $(\mathrm{z}=-1.807, p>.05)$ alt boyutlarından aldıkları puanlara göre ön-test ve son-test puanları arasında anlamlı bir fark yoktur.

\section{Öğretmenin eğitim programına ilişkin gözlem ve görüşleri}

Öğretmen ile form aracılığıyla bir görüşme gerçekleştirilmiş, bu görüşmeden elde edilen veriler araştırmacılar tarafindan incelenmiştir. Öğretmen görüş ve gözlemlerinin olumlu olduğu görülmüştür. Öğretmenden alınan bu olumlu gözlem geribildirimleri "Çocuklardaki olumlu değişimler” başlığında kategorize edilmiştir. 
Tablo 6.

Ögrretmen ile yapılan görüşmeden elde edilen verilerin analizi

\begin{tabular}{ll}
\hline & f \\
\hline Çocuklardaki olumlu değişimler & 2 \\
Sınıf içi kurallara uyum & 2 \\
Akran ilişkilerinde uyum & 2 \\
Derse aktif katılım & 1 \\
Yardım alma ve yardım etmede artış & 1 \\
Etkinlikleri sınıfta tekrar yapma isteği & \\
\hline
\end{tabular}

Öğretmen , "Sınıf içi kurallara uyum", "Akran ilişkilerinde uyum”, "Yardım alma ve yardım etmede artış" ve "Etkinlikleri sınıfta tekrar yapma isteği" için, "Sınıf içi kurallara daha çok uyduklarını görüyorum. Oturumlar sonrası bazı uygulamaları benim tekrar yapmamı istiyorlar. Bu durum sınıf içi kurallara ve birbirlerine uyumu arttırdl." şeklinde görüş bildirmiştir. "Derse aktif katılım" ve "Yardım alma ve yardım etmede artış" için "Gözlemlerim etkinliklere gönüllü katılmalarıydl. Bence bu çok değerli. Sinufta birbirlerine daha fazla yardım ettiklerini görmek sevindirici" şeklinde beyanda bulunmuştur.

\section{Çocukların eğitim programına ilişkin görüşleri}

Çocuklar ile formlar aracılığıyla yapılan görüşmelerin ardından veriler incelenmiş, bazı çocukların birden fazla temada görüş bildirmesi sebebiyle frekans çocuk sayısından fazladır. Çocuklar ile yapılan görüşmelerden alınan bilgiler "Eğitim Programının Katkıları" başlığında kategorize edilmiştir.

Tablo 7.

Çocuklar ile yapılan görüşmelerden alınan verilerin analizi

\begin{tabular}{ccc}
\hline & f & $\%$ \\
\hline Eğitim programının katkıları & 8 & 50.00 \\
Daha yakın akran ilişkileri & 6 & 37.50 \\
Daha iyi çizim yapma & 5 & 31.25 \\
Uygulamalara aktif katılım & 4 & 25.00 \\
Öğretmen övgüsünde artış & 2 & 12.50 \\
Merak güdüsünde artış & 1 & 6.25 \\
Aktivitelere daha fazla ilgi duyma & & \\
\hline
\end{tabular}

Tablo 7'de çocukların "Eğitim programının katkıları" hakkında görüşleri yer almaktadır. Bu kategoride "Daha iyi akran ilişkileri", "Daha iyi çizim yapma", "Uygulamalara aktif katılım", "Öğretmen övgüsünde artış", "Merak güdüsünde artış", "Aktivitelere daha fazla ilgi duyma" yer almaktadır. Bu konuda görüşlerini bildiren çocuklar, "Artık arkadaşlarımla daha iyi anlaşıyorum", "Öğretmenim bana daha fazla aferin diyor", "Artık daha fazla parmak kaldırıyorum" gibi ifadeler kullanmıştır.

\section{Ebeveynlerin eğitim programı ile ilgili izlenimleri}

Katılımcıların ebeveynleri ile yarı yapılandırılmış görüşme formu aracılığıyla yapılan görüşmenin ardından elde edilen veriler araştırmacılar tarafindan temalara dönüştürülerek içerik incelenmiş, frekans ve yüzdeler hesaplanmıştır. Bazı katılımcıların birden fazla temada görüş bildirmesi sebebiyle frekans sayısı katılımcı sayısından fazladır. 
Tablo 8.

Katılımcıların ebeveynleri ile yapılan görüşmeden elde edilen verilerin analizi

\begin{tabular}{lll}
\hline & $\mathrm{f}$ & $\%$ \\
\hline Eğitim programının katkıları & & 50.00 \\
Akademik becerilerde gelişim & 8 & 31.25 \\
İletişim becerilerinde artış & 5 & 18.75 \\
Öğretmenin olumlu geribildirimleri & 3 & 12.50 \\
$\quad$ Sosyal ilişki başlatmada artış & 2 & \\
Çocuklarının eğitim programı ile ilgili ev içi paylaşımları & & 50.00 \\
$\quad$ Evde etkinlik talep etme & 8 & 31.25 \\
Yeni materyal isteklerinde artış & 5 &
\end{tabular}

Ebeveynler ilk sırada "Eğitim programının katkıları" ile ilgili görüş paylaşmıștır. Bu kategoride "Akademik becerilerde gelişim", "İletişim becerilerinde artış", "Öğretmenin olumlu geribildirimleri" ve "Sosyal ilişki başlatmada artış" yer almaktadır. "Öğretmen çocuğumuzla ilgili artık çok daha iyi şeyler söylüyor", "Çocuğum sinıftaki arkadaşlarıyla daha iyi iletişim kuruyor" ve "Ben kalem tutuşunu daha iyi görüyorum. Dersi daha iyi anlıyor” gibi ifadeler kullanmışlardır.

Ebeveynler ikinci sırada ise "Çocuklarının eğitim programı ile ilgili ev içi paylaşımları" ile ilgili beyanda bulunmuştur. Bu kategoride "evde etkinlik talep etme" ve "Yeni materyal isteklerinde artış" yer almaktadır. Ebeveynler bu kategoride "Eskiden evde pek etkinlik istemezdi. Şimdi talep ediyor" ve "Artık yeni istekleri oluyor. Bazı eğitim setleri aldık. Sevindirici bir şey" gibi ifadeler kullanmıştır.

\section{TARTIŞMA, SONUÇ ve ÖNERILER}

Eğitim programının uygulanması sonucunda elde edilen bulgular incelendiğinde aktif öğrenmeye dayalı eğitim programının deney grubundaki çocukların Sosyal Yetkinlik düzeylerini arttırdığı; Kızgınlık-Saldırganlık ve Anksiyete-İçe dönüklük düzeylerini ise azalttığı sonucuna varılmıştır. Çocuklarla, çocukların okul öncesi öğretmeni ve aileleriyle sosyal geçerlik amacıyla yapılan görüşmelerde de eğitim programının etkililiğine dair olumlu görüşlerin ifade edildiği sonucuna varılmıştır.

Araştırma bulgularından ilki, kontrol grubunda yer alan çocukların Sosyal Yetkinlik KızgınlıkSaldırganlık ve Anksiyete-İ̧e dönüklük puanlarının ön-test ve son-test puanları açısından farklılaşmamasıdır. Bu durum ölçme aracının geçerlik ve güvenirlik çalışmalarından ve ölçme aracının kullanıldığ 1 diğer araştırmalarda elde edilen bulgularla kısmen çelişmektedir. Örneğin ölçeğin güvenirlik çalışmaları sırasında 3 ay arayla seçkisiz yöntemle seçilen 31-73 ay arasında takvim yaşına sahip 151 çocuğa ölçme araçlarının tekrar uygulandığı, Sosyal Yetkinlik ve Kızgınlık-Saldırganlık puanlarının son-test lehine anlamlı bir şekilde farklılaştı̆̆ı, Anksiyete-İçe dönüklük puanlarının ise farklılaşmadığı bulgulanmıştır (Çorapçı ve diğ., 2010). Ölçme aracının kullanıldığı diğer çalışmalarda ise, Atan ve Buluş (2018) kontrol grubundaki çocukların Sosyal Yetkinlik puanlarının son-test lehine farklılaştığını, ancak Anksiyete-İçe dönüklük ve Kızgınlık-Saldırganlık puanlarının farklılaşmadığını bulgularken; Uysal ve Bayrak (2018) ölçme aracının 80 maddeden oluşan formunu kullandıkları çalışmalarında kontrol grubundaki çocukların Sosyal Yetkinlik ve Davranış Değerlendirme Ölçeği öntest ve son-test toplam puanlarının farklılaşmadığını bulgulamıştır.

Araştırmalarda elde edilen çelişkili bulgular örneklem grubu ve araştırmaların gerçekleştirildiği tarih ile ilgili olabilir. Okul öncesi eğitiminin başında sınıfında akranlarıyla bir araya gelen çocuklar yeni bakış açılarının farkına varır, bu fikirlerden beslenir ve geliştirdikleri bu kişiler arası ilişkiler sayesinde sosyal yetkinlik düzeylerine katkı sunar, sosyal yetkinlikte, duygu düzenlemede ve özdüzenlemede meydana gelen değişimler anksiyete ve saldırganlık düzeylerinin azalmasına yardımcı olur (LaFreniere, 2002). Bu araştırmanın okul öncesi eğitimin başladığı güz döneminde gerçekleşmesi durumunda Sosyal Yetkinlik ve Davranış Değerlendirme Ölçeği alt boyutlarında hızlı bir değişim 
meydana gelebilirdi. Ancak ön-test ve son-testlerin Mart ve Mayıs aylarında gerçekleştirilmiş olması, bu periyotta nispeten daha esnek bir programın uygulanması, ön-test ve son-test arasında yalnızca iki ay olması gibi faktörler bu araştırmada kontrol grubundan elde edilen bulguların nedeni olabilir.

Araştırmanın bir diğer bulgusu, aktif öğrenmeye dayalı eğitim programının deney grubundaki çocukların Sosyal Yetkinlik düzeylerini arttırması; Kızgınlık-Saldırganlık ve Anksiyete-ǐ̉e dönüklük düzeylerini ise azaltmasıdır. Aktif öğrenme yaklaşımı ile geliştirilen programların farklı yaş gruplarındaki katılımcılara uygulanabildiği ve pek çok yetinin gelişimine katkı sunduğu bildirilmektedir. Örneğin aktif öğrenme yaklaşımı ile geliştirilen programların hemşire adaylarının mesleki yeterliklerinde ve yaratıcılık düzeylerinde (Shin, Sok, Hyun ve Kim, 2015), öğretmenlerin mesleki gelişimlerinde (Van den Bergh, Ros ve Beijaard, 2014), öğrencilerin fen, teknoloji, mühendislik ve matematik (STEM) derslerindeki başarı düzeylerinde (Freeman ve diğ., 2014), üniversite öğrencilerinin mesleki ilgi ve kariyer planlamalarında (Sivan, Leung, Woon ve Kember, 2000), ortaokul öğrencilerinin akademik başarılarının artmasında ve fen derslerine yönelik tutumlarında (Tandoğan ve Oran, 2007), ortaokul öğrencilerinin eleştirel düşünme becerilerinde (Koç, 2011), ilkokul öğrencilerinin erken öğrenme sürecinde (Stephen, Ellis ve Martlew, 2010) okul öncesi çocukların problem çözme becerilerinde (Anlıak, Ş. ve Dinçer, Ç., 2005) etkili olduğu bulgulanmıştır. Bu araştırmada elde edilen bulgular, aktif öğrenmenin yalnızca akademik ya da mesleki becerilerin gelişimine katkı sunabilen bir yöntem olmadığı, aynı zamanda okul öncesi dönemdeki çocukların sosyal ve duygusal gelişimlerine de katkı sunabildiğini ortaya koymaktadır.

Aktif öğrenme yaklaşımı ile hazırlanan programın deney grubundaki çocukların sosyal yetkinlik düzeyini yükseltmesi, anksiyete-içe dönüklük ve kızgınlık-saldırganlık düzeylerini azaltması, erken çocukluk döneminde daha belirgin olmak üzere, bir alanda ortaya konan gelişimin diğer alanları da etkilemesi ile alakalı olduğu söylenebilir. Örneğin, okul öncesi dönemde sınıf içi akran ilişkilerinin gelişimi, sınıf dışı sosyal ilişkileri de etkileyebilmekte, bu olumlu sosyal değişim, anksiyete ve saldırganlık düzeyini azaltmakta, oluşan bu pozitif tablo öz-düzenleme becerilerini de geliştirmekte, özdüzenleme becerilerinin gelişimi de gelecekteki akademik başarının önemli bir yordayıcısı olmaktadır (Hemmeter, Snyder, Fox ve Algina, 2016; LaFreniere, 2002; Mian, Wainwright, Briggs-Gowan ve Carter, 2011). Ancak unutulmamalıdır ki, bir basamakta ortaya konan gelişim diğer alanları nasıl olumlu etkiliyorsa, bir alanda ortaya çıkan olumsuz bir durum başka bir alanı olumsuz etkileyebilir. Örneğin erken çocuklukta anksiyete düzeyinin yüksek olması gelecekte anksiyete bozukluğuna neden olmakta (Kagan ve Snidman, 1999), erken çocukluk dönemindeki düşük sosyal yetkinlik ise yetişkinlikte kriminal bir yaşam tarzına sahip olmanın, madde kullanımının, okul terkinin (Jones, Greenberg ve Crowley, 2015), uyum ve davranış problemlerinin (Bornstein, Hahn ve Haynes, 2010) önemli bir nedeni olmaktadır. Bu nedenle koruyucu, önleyici programlar geliştirmek ve geliştirilen programların yaygın bir şekilde uygulanmasını sağlamak, okul öncesi dönemdeki çocukların sosyal ve duygusal gelişimleri adına önem taşımaktadır.

Eğitim programının başarıya kavuşmasındaki bir diğer faktör, aktif öğrenmenin sosyal etkileşimi temel alan, öğrenenin duygularına, düşüncelerine ve ihtiyaçlarına odaklanan, bireyleri sorumluluk almaya ve fikirlerini açıklamaya teşvik eden bir yaklaşım olmasıdır (Yıldız-Demirtaş, 2015). Eğitim programının sosyal etkileşim içermesinin yanında çocuklarla, çocukların aileleriyle ve öğretmeni ile yapılan görüşmelerde, çocukların eğitim programındaki bazı teknikleri ve etkinlikleri daha sonra evde ya da sınıfta yeniden deneyimlemek istedikleri, ailelerin yeni materyal alarak ev içinde daha fazla aktivite gerçekleştirdikleri, öğretmenin sınıfta bu tekniklerden ve etkinliklerden yararlandığı öğrenilmiştir.

Deney grubunda elde edilen bulgular, okul öncesi eğitimin yaygınlaşmasının ve niteliğinin artmasının önleyici ve koruyucu sonuçlar doğuracağını ortaya koymaktadır. Milli Eğitim Bakanlığı (2018) verilerine göre, 2017-2018 eğitim yılında okullaşma oranının 3-5 yaş için \%38.52, 4-5 yaş için $\% 50.42,5$ yaş için okullaşma oran $\% 66.88$ olduğu, 2012-2013 yılından bu yana da okul öncesi eğitime katılımın artan bir seyir izlediği görülmektedir. Elbette Türkiye'de okul öncesi eğitime katılım oranının her yıl artması yüz güldüren önemli bir gelişmedir. Ancak OECD ülkelerinde 3 yaş için \% $\% 1$, 4 yaş için $\% 86$, son olarak 5 yaş için okullaşma oranının $\% 95$ olduğu düşünüldüğünde (Kazu ve Y1lmaz, 2018), Türkiye'de okul öncesi eğitime katılımı arttırıcı politikalara ihtiyaç duyulduğu sonucu ortaya çıkmaktadır. Ayrıca aktif öğrenme yaklaşımının her yaş grubunda farklı amaçlarla etkili olarak kullanılabilen bir yaklaşım olduğu düşünülerek, öğretmenlere hizmet içi eğitimleri içerisinde; öğretmen adaylarına lisans eğitimleri içerisinde gerekli becerileri ve teknik bilgiyi kazandırmak öneri olarak 
sunulabilir. Ayrıca sosyal yetkinlik ile ilgili araştırmalara çevresel ve ailesel faktörleri dahil etmek daha bütüncül bir değerlendirmeyi sağlayabilir, daha yetkin eğitim programlarının hazırlanmasına olanak sağlanabilir.

\section{KAYNAKÇA}

Açıkgöz, K. Ü. (2013). Aktif Öğrenme. Izmir: Eğitim Dünyası Yayınları.

Anlıak, Ş. ve Dinçer, Ç. (2005) Farklı Eğitim Yaklaşımları Uygulayan Okul Öncesi Eğitim Kurumlarına Devam Eden Çocukların Kişiler Arası Problem Çözme Becerilerinin Değerlendirilmesi. Ankara Üniversitesi Eğitim Bilimleri Fakültesi Dergisi, yıl: 2005, cilt: 38, sayı: 1, 149-166.

Atan, A. ve Buluş, M. (2018). The effect of family communication skills psycho-educational program on 5-6 years old children's social-emotional adjustment. Pamukkale Üniversitesi Eğitim Fakültesi Dergisi, (44), 213230 .

Avcıŏlu, H. (2003). Okulöncesi dönemdeki çocuklara sosyal becerilerin öğretilmesinde işbirlikçi öğrenme yöntemi ile sunulan öğretim programının etkililiğinin incelenmesi. OMEP Dünya Konsey

Toplantis1 ve Konferans1 (ss. 490-504).

Barnett, W. S., Jung, K., Yarosz, D. J., Thomas, J., Hornbeck, A., Stechuk, R. ve Burns, S. (2008). Educational effects of the Tools of the Mind curriculum: A randomized trial. Early childhood research quarterly, 23(3), 299-313.

Büyüköztürk, Ş. (2007). Sosyal bilimler için veri analizi el kitabı: İstatistik, araştırma deseni, SPSS uygulamaları ve yorum. Ankara: Pegem Yayıncilık.

Bornstein, M. H., Hahn, C. S., ve Haynes, O. M. (2010). Social competence, externalizing, and internalizing behavioral adjustment from early childhood through early adolescence: Developmental cascades. Development and Psychopathology, 22(4), 717-735.

Campbell SB (2002) Behavior problems in preschool children: Clinical and developmental issues. Guilford, New York.

Chen, C.-C., Huang, C., Gribbins, M., \& Swan, K. (2018). Gamify online courses with tools built into your learning management system (LMS) to enhance self-determined and active learning. Online Learning, $22(3), 41-54$

Cleary T., J., \& Zimmerman, B., J., (2004), Self-regulation empowernt program: a School-based program to enhance self-regulated and self-motivated cycles of student learning, Psychology in the Schools, 41 (5), 537-550.

Coplan, R. J., Ooi, L. L., Xiao, B. ve Rose - Krasnor, L. (2018). Assessment and implications of social withdrawal in early childhood: A first look at social avoidance. Social Development, 27(1), 125-139.

Çelik, Ö. ve Buluç, B. (2016). Disiplinler arası yaklaşımla değer öğretiminde yaratıcı drama yönteminin Duman, G. B. (2013). Türkçenin yabancı dil olarak öğretiminde materyal geliştirme ve materyallerin etkin kullanımı.

Çorapçı, F., Aksan, N., Arslan-Yalçın, D. ve Yağmurlu, B. (2010). Okul öncesi dönemde duygusal, davranışsal ve sosyal uyum taraması: Sosyal yetkinlik ve davranış değerlendirme-30 ölçeği. Çocuk ve Gençlik Ruh Sağglı̆̆ Dergisi, 17(2), 63-74.

Dignath C., Buettner G., \& Langfeldt, H-P., (2008), How can primary school students learn self-regulated llearning strategies most effectively? A meta-analysis on self-regulation training programmes, Educational Research Review, 3, 101-129.

Duman, G. B. (2013). Türkçenin yabancı dil olarak öğretiminde materyal geliştirme ve materyallerin etkin kullanımı. Ana Dili Ĕ̈itimi Dergisi, 1(2), 1-8.

Elias, C. L. ve Berk, L. E. (2002). Self-regulation in young children: Is there a role for sociodramatic play? Early Childhood Research Quarterly, 17(2), 216-238.

Freeman, S., Eddy, S. L., McDonough, M., Smith, M. K., Okoroafor, N., Jordt, H. ve Wenderoth, M. P. (2014). Active learning increases student performance in science, engineering, and mathematics. Proceedings of the National Academy of Sciences, 111(23), 8410-8415. 
Hemmeter, M. L., Snyder, P. A., Fox, L. ve Algina, J. (2016). Evaluating the implementation of the Pyramid Model for promoting social-emotional competence in early childhood classrooms. Topics in Early Childhood Special Education, 36(3), 133-146.

Henson, K.T. (2003). Foundations for learner-centered educational: A knowledge base. Education 124 (1), 5-16.

Hofmann, W., Schmeichel, B. J. ve Baddeley, A. D. (2012). Executive functions and self-regulation. Trends in Cognitive Sciences, 16(3), 174-180.

Johnson, R. T. ve Johnson, D. W. (2008). Active learning: Cooperation in the classroom. The Annual Report of Educational Psychology in Japan, 47, 29-30.

Jones, D. E., Greenberg, M. ve Crowley, M. (2015). Early social-emotional functioning and public health: The relationship between kindergarten social competence and future wellness. American Journal of Public Health, 105(11), 2283-2290.

Kagan, J. ve Snidman, N. (1999). Early childhood predictors of adult anxiety disorders. Biological Psychiatry, 46(11), 1536-1541.

Kazu, İ. Y. ve Yılmaz, M. (2018). Ükemizdeki okul öncesi eğitimin bazı veriler açısından OECD ve AB üyesi ülkeleri ile karşılaştırılması. Turkish Journal of Educational Studies, 5(2), 64-75.

Koç, C. (2011). Aktif öğrenmenin okuduğunu anlama ve eleştirel düşünme üzerindeki etkileri. Cumhuriyet Üniversitesi Edebiyat Fakültesi Sosyal Bilimler Dergisi, 35(1), 28-37.

Ladd, G. W. (1999). Peer relationships and social competence during early and middle childhood. Annual Review of Psychology, 50(1), 333-359.

LaFreniere, P. J. ve Dumas, J. E. (1996). Social competence and behavior evaluation in children ages 3 to 6 years: The short form (SCBE-30). Psychological Assessment, 8(4), 369-377.

LaFreniere, P., Masataka, N., Butovskaya, M., Chen, Q., Auxiliadora Dessen, M., Atwanger, K., ... ve Frigerio,

A. (2002). Cross-cultural analysis of social competence and behavior problems in preschoolers. Early Education and Development, 13(2), 201-220.

Mian, N. D., Wainwright, L., Briggs-Gowan, M. J., \& Carter, A. S. (2011). An ecological risk model for early childhood anxiety: The importance of early child symptoms and temperament. Journal of Abnormal Child Psychology, 39(4), 501-512.

Möller, E. L., Nikolić, M., Majdandžić, M., \& Bögels, S. M. (2016). Associations between maternal and paternal parenting behaviors, anxiety and its precursors in early childhood: A meta-analysis. Clinical Psychology Review, 45, 17-33.

Ogelman, H. G. ve Topaloğlu, Z. Ç. (2014). 4-5 yaş çocuklarının sosyal yetkinlik, saldırganlık, kaygı düzeyleri

ile anne-babalarının ebeveyn özyeterliği algısı arasındaki ilişkilerin incelenmesi. Abant İzzet Baysal Üniversitesi Ĕ̌itim Fakültesi Dergisi, 14(1), 241-271.

Ott, L. E., Carpenter, T. S., Hamilton, D. S. ve LaCourse, W. R. (2018). Discovery Learning: Development of a Unique Active Learning Environment for Introductory Chemistry. Journal of the Scholarship of Teaching and Learning, 18(4), 161-180.

Pino-Pasternak, D \& Whitebread, D., (2010), The role of parenting in children's self-regulated learning, Educational Research Review, 5, 220-242.

Prince, M. (2004). Does active learning work? A review of the research. Journal of Engineering Education, 93(3), 223-231.

Ramdass, D. \& Zimmerman, B., J., (2011), Developing Self-Regulation Skills: The Important Role of Homework , Journal of Advanced Academics 22 : 2, 194-218.

Roberts, J. E., King-Thomas, L., \& Boccia, M. L. (2007). Behavioral indexes of the efficacy of sensory integration therapy. American Journal of Occupational Therapy, 61, 555-562.

Schunk, D. (2005). Commentary on self-regulation in school contexts. Learning and Instruction, 15, $173-177$.

Schunk, D. (2010). Goal setting and self-efficacy during self-regulated learning, Educational Pyschologist, 25(1), 71-86.

Shin, H., Sok, S., Hyun, K. S., ve Kim, M. J. (2015). Competency and an active learning program in undergraduate nursing education. Journal of Advanced Nursing, 71(3), 591-598. 
Sibona, C. ve Pourrezajourshari, S. (2018). The impact of teaching approaches and ordering on IT project management: Active learning vs. lecturing. Information Systems Education Journal, 16(5), 66-77.

Schindler, H. S., Kholoptseva, J., Oh, S. S., Yoshikawa, H., Duncan, G. J., Magnuson, K. A., \& Shonkoff, J. P. (2015). Maximizing the potential of early childhood education to prevent externalizing behavior problems: A meta-analysis. Journal of School Psychology, 53(3), 243-263.

Schwartz, I. S., \& Baer, D. M. (1991). Social validity assessments: Is current practice state of the art?. Journal of Applied Behavior Analysis, 24(2), 189-204.

Sivan, A., Leung, R. W., Woon, C. C. ve Kember, D. (2000). An implementation of active learning and its effect on the quality of student learning. Innovations in education and training international, 37(4), 381-389.

Stephen, C., Ellis, J., ve Martlew, J. (2010).Taking active learning into the primary school: a matter of new practices?. International Journal of Early Years Education. Volume 18, 2010, 315-329.

Tandoğan, R. O. ve Orhan, A. (2007). The effects of problem-based active learning in science education on students' academic achievement, attitude and concept learning. Online Submission, 3(1), 71-81.

Türksoy, E. ve Taşlıdere, E. (2016). Aktif öğrenme teknikleri ile zenginleştirilmiş öğretim yönteminin 5. Sinıf öğrencilerinin fen ve teknoloji dersi akademik başarı ve tutumları üzerine etkisi. Ahi Evran Üniversitesi Kırşehir Eğitim Fakültesi Dergisi, 17, (1) 57-77.

Ursache, A., Blair, C. ve Raver, C. C. (2012). The promotion of self - regulation as a means of enhancing school readiness and early achievement in children at risk for school failure. Child Development Perspectives, 6(2), 122-128.

Uysal-Bayrak, H. ve Akman, B. (2018). Adaptation of the" Incredible Years Child Training Program" and investigation of the effectiveness of the program. Educational Sciences: Theory and Practice, 18(2), 397-425.

Ün-Çelik, S., Şenocak, E., Bayrakçeken, S., Taşkesenligil, Y. ve Doymuş, K. (2005) Aktif öğrenme stratejileri üzerine bir derleme çalışması, Kazım Karabekir Eğitim Fakültesi Dergisi, 11, 155-185.

Van den Bergh, L., Ros, A. ve Beijaard, D. (2014). Improving teacher feedback during active learning: Effects of a professional development program. American educational research journal, 51(4), 772-809.

Weiland, C. ve Yoshikawa, H. (2013). Impacts of a prekindergarten program on children's mathematics, language, literacy, executive function, and emotional skills. Child Development, 84(6), 2112-2130.

Yıldız-Demirtaş, V. (2015). Aktif öğrenme ve işbirlikli öğrenme yöntem ve teknikleri. İçinde B. Doğan ve V. Alkan (Eds.) Ögretim Illke ve Yöntemleri. (ss. 245-288). Ankara: Ĕ̆iten Kitap. 